\title{
PELATIHAN MANAJEMEN KEUANGANTERPADU PADA UD. DUA DEWI KERIPIK NANGKA Q-ECCO DESA WONOSARI KECAMATAN PUGER JEMBER
}

\author{
Arik Susbiyani, Nursaid \\ Jurusan Akuntansi Universitas Muhammadiyah Jember \\ ariksusbiyani@unmuhjember.ac.id
}

\begin{abstract}
ABSTRAK
Tujuan utama kegiatan pengabdian berjudul "Pelatihan Manajemen Keuangan Pada UD. Dua Dewi Keripik Nangka Q-Ecco Puger "adalah untuk mengatasi permasalahan yang dihadapi oleh mitra pengusaha, diantaranya adalah, yaitu: (1) Pengusaha dalam menjalankan usahanya belum memahami manajemen keuangan akibatnya setiap pengambilan keputusan hanya berdasarkan asumsi semata-mata bukan pada kondisi sebenarnya keuangan. (2) Terbatasnya pengetahuan mitra tentang pencatatan keuangannya, akibatnya pengrajin tidak dapat mengakses dana tanggung jawab sosial perusahaan (CSR) dari BUMN atau program Kredit Usaha Rakyat (KUR).

Target khusus dalam program Pengabdian ini adalah untuk meningkatkan kemampuan pengusaha dalam melaksanakan manajemen usaha terpadu (manajemen keuangan, manajemen penjualan, dan laporan keuangan), sehingga kontinuitas usaha dapat dipertahankan karena puluhan masyarakat didesa ini menggantungkan hidup mereka pada usaha keripik nangka ini.

Metode pendekatan yang ditawarkan untuk menyelesaikan masalah mitra program pengabdian adalah bidang manajemen keuangan dan pelaporan keuangan yang tahapan: (a) Penguatan bidang manajemen keuangan sebagai upaya untuk meningkatkan kompetensi mitra usaha dalam pengelolaan keuangan. (b) Pelatihan dan pendampingan laporan keuangan sebagai upaya untuk mengatasi sulitnya mitra akses dana bank. (c) Pemantauan, evaluasi dan pelaporan.

Hasil yang telah dicapai dari kegiatan pelatihan ini adalah mitra dan binaan mitra memahami manajemen keuangan dan memahami proses akuntansi dalam menyiapkan laporan keuangan. Selama proses evaluasi dan pemantaun, mitra secara bertahap membenahi laporan keuangan.
\end{abstract}

Kata Kunci: Manajemen Keuangan, Laporan Keuangan, Keripik Nangka 


\begin{abstract}
ABSTARCT
The main objective of the service activity entitled "Financial Management Training at UD. UD. Dua Dewi Keripik Nangka Q-Ecco Puger"are to solve the problems faced by business partners, including: (1) Entrepreneurs in running their businesses do not understand financial management, as a result every decision making is based solely on assumptions and not on actual financial conditions. (2) Limited knowledge of partners about financial records, as a result craftsmen cannot access corporate social responsibility (CSR) funds from BUMN or the People's Business Credit (KUR) program.

The specific target in this Community Service program is to improve the ability of entrepreneurs in implementing integrated business management (financial management, sales management, and financial reports). So that business continuity can be maintained because dozens of people in this village depend their lives on this jackfruit chips business.

The approach method offered to solve the community service program partner's problems is in the field of financial management and financial reporting which stages: Strengthening the field of financial management as an effort to improve the competence of business partners in financial management. (b) Financial reporting training and assistance as an effort to overcome difficulties for partners to access bank funds. (c) Monitoring, evaluation and reporting.

The results that have been achieved from this training activity are that the partners and fostered partners understand financial management and understand the accounting process in preparing financial reports. During the evaluation and monitoring process partners gradually fix financial reports.
\end{abstract}

Keywords: Financial Management, Financial Statements, jackfruit chips 


\section{Jurnal ABDIMAS INDEPENDEN}

Vol. 2, No. 1, Mei 2021

\section{PENDAHULUAN}

Tanaman hortikultura mendapatkan perhatian besar dari pemerintah karena telah terbukti peranannya sebagai komoditi yang dapat dipakai sebagai sumber pertumbuhan baru sektor pertanian (Soekartawi, 1993). Buah nangka diantaranya merupakan tanaman yang mudah untuk dicari dan hasilnya sangat melimpah ketika panen raya. Dengan adanya pengolahan (agroindustri) nangka, maka dapat menawarkan bahan pangan sesuai dengan selera konsumen serta mempunyai nilai ekonomi yang tinggi dan daya tahan cukup lama (Widyastuti, 1995).

Salah satu agro industri yang mengolah Nangka menjadi keripik Nangka adalah UD Dua Dewi, berdiri sejak tahun 2013 dengan memproduksi berbagai macam produk seperti keripik nangka, keripik pisang, keripik pepaya, keripik salak, kopi pinang dan keripik edamame. UD dua Dewi memiliki 12 karyawan yang bekerja untuk mengolah produk tersebut. Namun pada saat ini, keripik nangka menjadi produk andalan UD Dua Dewi karena pemasaran keripik nangka sendiri tidak hanya dilakukan di dalam negeri bahkan telah dipasarkan hingga keluar negeri. Permintaan yang tinggi akan keripik nangka dan adanya prospek pasar yang baik membuat keripik nangka terus meningkatkan produksi. Hal inidapatterlihat pada produksi keripik nangka UD Dua Dewi yang mengalami peningkatan. Peningkatan produksi ini terjadi terutama pada saat musim panen raya buah nangka. Pada saat musim panen raya, ketersediaan buah Nangka menjadi melimpah sehingga harga jual buah Nangka menjadi rendah dan terjadi persaingan antar petani untuk menjual buah nangka. Petani menjual buah Nangka dengan harga murah sebab jikad ibiarkan dan tidakdijualbuahnangkamenjadicepatrusak.

Proses produksi telah menggunakan vacuum frying yang mampu mengoreng $30 \mathrm{~kg}$ per hari. Selain itu, peralatan ini (vacuum frying) dilengkapi pendingin system kolam dengan pompa hight vacuum. Peralatan ini menggunakan 2 pompa dengan kekuatan 1000watt setiap pompa sekali 
produksi, kini hanya menggunakan 1 pompa.

Namun dalam perkembangannnya, persoalan yang dihadapi oleh mitra adalah belum adanya pemisahan manajemen keuangan usaha dan rumah tangga secara jelas, sehingga mitra tidak mengetahui apakah usahanya dalam keadaan untung atau rugi secara akuntansi. Mitra membutuhkkan data dan informasi yang memadai sehingga pemilik dapat memperhitungkan keuntungan yang diperoleh, mengetahui berapa tambahan modal yang dicapai, dan juga dapat mengetahui bagaimana keseimbangan hak dan kewajiban yang dimiliki. Sehingga setiap keputusan yang diambil oleh pemilik dalam mengembangkan usahanya akan didasarkan pada kondisi konkrit keuangan bukan hanya didasarkan pada asumsi semata. Selain itu walaupun pemerintah telah mengeluarkan kebijakan berupa program pembiayaan UMKM untuk menjadi solusi pembiayaan modal yang efektif bagi UMKM, namun selama ini mitra pengrajin terkendala akses terhadap perbankan untuk mendapatkan pembiayaaan. Penyaluran KUR masih relatif sangat rendah karena bank yang ditunjuk sebagai penyalur KUR sangat berhati-hati dalam penyaluran kredit. Mitra belum memiliki laporan keuangan seperti yang disyaratkan oleh pihak perbankan, akibatnya bank tidak mendapatkan informasi yang memadai terkait kondisi mitra.

Berdasarkan latar belakang situasi seperti dijelaskan di atas, masalah yang dihadapi pengrajin sebagai mitra dalam usahanya antara lain: 1)Mitra merupakan pengusaha yang belum memiliki manajemen keuangan yang baik, hal ini ditunjukkan dengan tidak adanya pemisahan manajemen keuangan usaha dan rumah tangga secara jelas. Akibatnya, mitra tidak mengetahui apakah usahanya dalam kondisi untung atau rugi. Perlu pembinaan dan pendampingan dalam melaksanakan manajemen keuangan untuk memperoleh data dan informasi yang memadai sehingga mitra dapat memperhitungkan keuntungan yang diperoleh, mengetahui berapa tambahan modal yang dicapai, dan juga dapat mengetahui bagaimana keseimbangan hak dan kewajiban yang dimiliki. Sehingga setiap keputusan yang diambil oleh pemilik dalam mengembangkan usahanya akan didasarkan pada kondisi konkrit keuangan bukan hanya 


\section{Jurnal ABDIMAS INDEPENDEN}

Vol. 2, No. 1, Mei 2021

didasarkan pada asumsi semata. 2) Terbatasnya pengetahuan mitra dalam melaksanakan pencatatan keuangannya. Penyebabnya karena kurangnnya pemahaman akuntansi atau tata buku, kurang disiplin dalam melaksanakan pembukuan akuntansi, serta tidak adanya dana yang cukup untuk mempekerjakan akuntan. Perlu pembinaan dan pendampingan dalam menyusun laporan keuangan sesuai SAK ETAP.

Justifikasi pengusul bersama mitra dalam menentukan persoalan prioritas adalah:

a. Persoalan manajemen usaha yang baik masih belum dimiliki oleh mitra, hal ini dapat diperbaiki dengan penguatan bidang manajemen keuangan sehingga terwujudnya usaha mikro yang tangguh dengan dikelola secara profesional.

b. Persoalan mitra usaha yang sulit untuk mengakses pembiayaan usaha mikro dari bank, misalnya dana corporate social responsibility (CSR) dari Badan Usaha Milik Negara atau Badan Usaha Milik Swasta untuk pembiayaan pengusaha mikro atau memanfaatkan program pemerintah untuk pengusaha mikro dalam bentuk Kredit Usaha Rakyat (KUR). Sehingga dibutuhkan pembinaan dan pendampingan dalam menyusun laporan keuangan sesuai SAK ETAP agar mitra dapat memberikan informasi keuangan yang memadai kepada Bank.

\section{METODE KEGIATAN}

Metode pendekatan yang digunakan untuk menyelesaikan persoalan mitra adalah meliputi tahapan :Penguatan bidang manajemen keuangan dilakukan melalui pelatihan dan pendampingan untuk melakukan analisis usaha melalui segalaaktivitas usaha mikro yang berhubungan dengan bagaimana pelaku bisnis memperoleh dana, menggunakan dana dan mengelola asset sesuai dengan tujuan usaha secara menyeluruh. Tahapan yang akan dilaksanakan dalam program ini adalah dalam bentuk: 1)Pelatihan Manajemen Keuangan.Kegiatan ini dimaksudkan untuk meningkatkan kompetensi mitra 
usaha dalam pengelolaan keuangan sebab dana merupakan darah bagi kehidupan kegiatan usaha. Aspek yang menjadi perhatian dalam pelatihan manajemen keuangan adalah: (a) aspek sumber dana, (b) Perencanaan dan penggunaan dana, dan (c) Pengawasan /pengendalian keuangan. 2). Pelatihan dan Pendampingan penyusunan laporan keuangan sesuai SAK EMKM. Pelatihan dan pendampingan penyusunan laporan keuangan dimaksudkan agar mitra memiliki pemahaman tentang penyusunan laporan keuangan dan manfaat laporan keuangan bagi pelaku usaha (Rudiantoro dan Siregar, 2012). Sehingga mitra mampu menyusun laporan keuangan secara periodik. Materi yang disampaikan pada kegiatan ini adalah: tahapan dalam proses akuntansi yang meliputi: pembuatan jurnal, buku besar, neraca saldo, dan penyusunan laporan keuangan.

\section{HASIL DAN PEMBAHASAN}

\section{Gambaran Kegiatan Pelatihan}

Hasil kegiatan Program pengabdian kepada masyarakat pada Pada UD. Dua Dewi Keripik Nangka Q-Ecco Desa Wonosari Kecamatan Puger Jember yang telah dilakukan oleh tim dapat dijelaskan sebagai berikut:

1. Penguatan Bidang Manajemen Keuangan

Kegiatan penguatan bidang manajemen keuangan telah dilakukan oleh dosen dan mahasiswa. Kegiatan ini dikemas dalam bentuk pelatihan dan pendampingan, yaitu dalam bentuk analisis usaha melalui segala aktivitas usaha mikro yang berhubungan dengan bagaimana pelaku bisnis memperoleh dana, menggunakan dana dan mengelola asset sesuai dengan tujuan usaha. Kegiatan ini dilaksanakan di rumah salah satubinaan UD. Dua Dewi Keripik Nangka Q-Ecco yang berada di Desa Wonosari Kecamatan Puger Jember.

Tahapan yang telah dilaksanakan dalam tahapan ini adalah meliputi:

a. Pelatihan manajemen keuangan

a. Pelatihan Analisis Rasio Piutang

2. Pelatihan dan Pendampingan penyusunan laporan keuangan sederhana. 


\section{Jurnal ABDIMAS INDEPENDEN}

Vol. 2, No. 1, Mei 2021

Pelatihan dan Pendampingan penyusunan laporan keuangan sederhana telah dilaksanakan oleh dosen dan mahasiswa Fakultas Ekonomi Universitas Muhammadiyah Jember pada hari dan tanggal yang sama yaitu tanggal 3 Maret 2021. Kegiatan ini dimaksudkan agar mitra memiliki pemahaman tentang penyusunan laporan keuangan dan manfaat laporan keuangan.

Materi yang disampaikan pada kegiatan ini adalah:

a. Materi tentang standar dokumen/bukti transaksi.

b. Pelatihan dan pendampingan pembuatan jurnal, buku besar, neraca saldo, dan penyusunan laporan keuangan.

\section{Tolak Ukur Keberhasilan Program Pengabdian}

Orientasi program pelatihan manajemen keuangan adalah penguatan dibidang manajemen keuangan. Penguatan bidang manajemen keuangan dilakukan melalui pelatihan dan pendampingan. Adapun tolak ukur keberhasilannya adalah:

a) Mitra dapat melakukan analisis usaha melalui segala aktivitas usaha mikro yang berhubungan dengan bagaimana pelaku bisnis memperoleh dana, menggunakan dana dan mengelola asset sesuai dengan tujuan usaha secara menyeluruh. Selain itu, mitra dapat melakukan pengelolaan piutang secara optimal dan memiliki pedoman untuk menganalisis kelayakan calon pembeli dalam menilai resiko kredit untuk menghindari risiko piutang tidak tertagih.

b) Mitra mampu menyusun laporan keungan sederhana yaitu yang terdiri dari tahapan pembuatan jurnal, buku besar, neraca saldo, dan penyusunan laporan keuangan. 


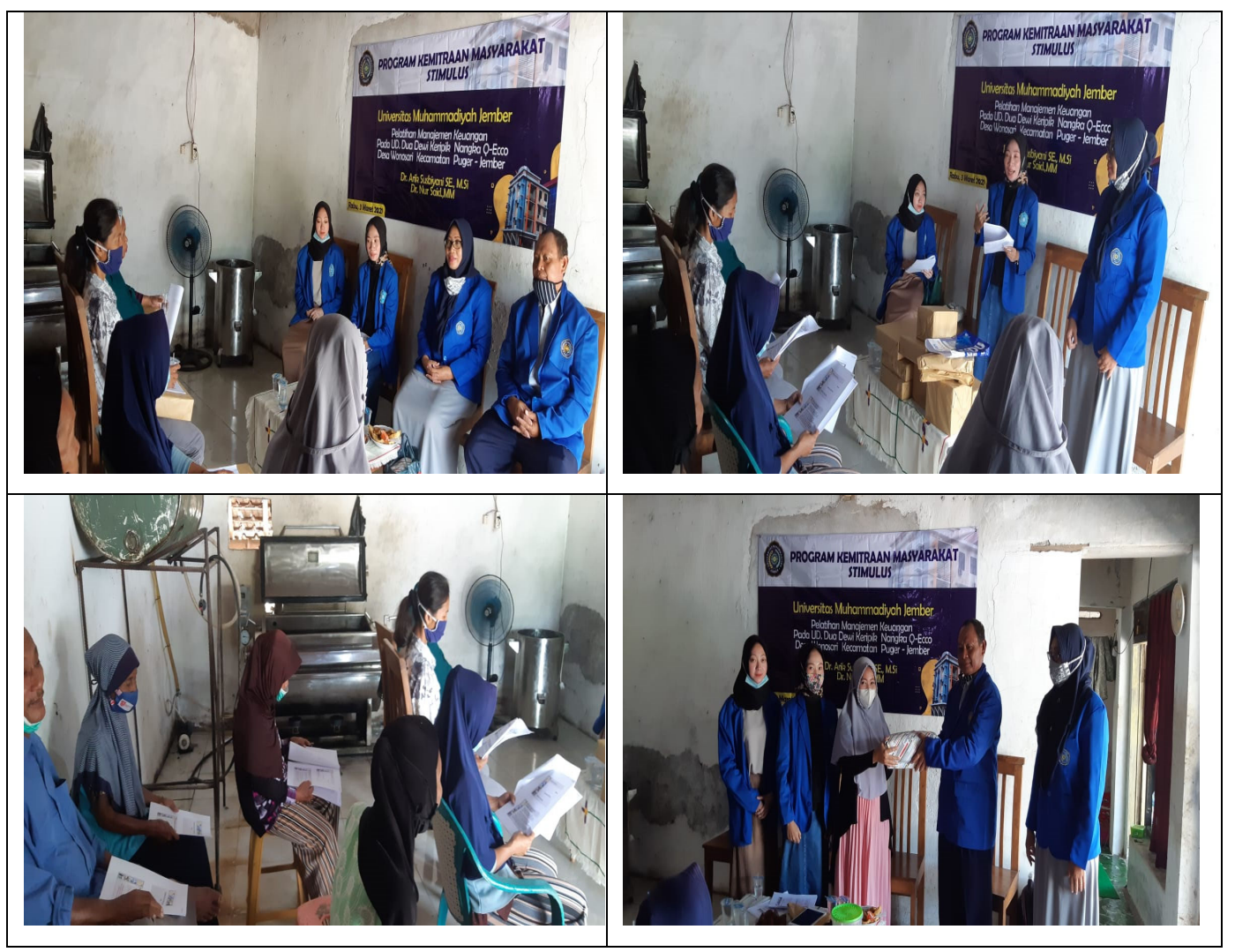

Gambar1: Kegiatan Pengabdian

\section{SIMPULAN DAN SARAN}

\section{Kesimpulan}

Hasil kegiatan Program Kemitraan Masyarakat pada UD. Dua Dewi Keripik Nangka Q-Ecco Desa Wonosari Kecamatan Puger Jember menekankan pada manajemen keuangan terpadu menunjukkan bahwa:

1. Mitra dapat melakukan pengelolaan keuangan secara optimal dan memiliki pengetahuan tentang bagaimana mengelola keuangan.

2. Mitra secara bertahap memperbaiki proses penyusunan laporan keungan sesuai dengan proses akuntansi yang terdiri dari tahapan pembuatan jurnal, buku besar, neraca saldo, dan penyusunan laporan keuangan.

\section{Saran}

Keberhasilan program pengabdian ini dengan menekankan pada perubahan pengelolaan secara tradisonal ke manajemen keuangan terpadu, maka hendaknya pendekatan ini dapat disebarluaskan kepada UMKM yang ada di 


\section{Jurnal ABDIMAS INDEPENDEN}

Kecamatan Puger Kabupaten Jember.

\section{UCAPAN TERIMA KASIH}

Tim pengabdian secara khusus mengucapkan terima kasih yang sebesarbesarnya kepada semua pihak yang telah memfasilitasi terlaksananya kegiatan pengabdian. Tim pengabdian banyak menerima bimbingan, petunjuk, dan bantuan serta support dari berbagai pihak baik yang bersifat moral maupun material. Pada kesempatan ini penulis menyampaikan rasa terima kasih yang sebesar-besarnya kepada:

a. Lembaga Penelitan dan Pengabdian Kepada Masyarakat (LPPM) Universitas Muhammadiyah Jember yang telah mendanai kegiatan pengabdian.

b. Pimpinan dan segenap mitra binaan UD. Dua Dewi Keripik Nangka Q-Ecco di Desa Wonosari Kecamatan Puger Jember.

c. Mahasiswa program studi akuntansi FE UM Jember yang telah membantu selama proses kegiatan pengabdian.

\section{DAFTAR PUSTAKA}

Al Haryon Jusuf. 2001. Dasar-dasar akuntansi Jilid 2. Yogyakarta. STIE YKPN

Husnan, Suad 2002. Dasar-Dasar Manajemen Keuangan.Yogyakarta: UPPAMP YKPN.

Horne, James C. Van dan John M. Wachowicz, Jr. 1998. Prinsip-prinsip Manajeman Keuangan. Jakarta: Salemba Empat.

Rudiantoro, R dan Siregar, S. 2012. Kualitas Laporan Keuangan UMKM Serta Prospek Implementasi SAK ETAP. Jurnal Akuntansi dan Keuangan Indonesia. Volume 9 - No. 1. h 1-27.

Soekartawi. 2001. Ilmu Usaha tani: Untuk Pengembangan Petani Kecil. UI Press, Jakarta. 
Rudiantoro, R dan Siregar, S. 2012. Kualitas Laporan Keuangan UMKM Serta Prospek Implementasi SAK ETAP. Jurnal Akuntansi dan Keuangan Indonesia Volume 9 - No. 1. h 1-27.

Widyastuti, Y. E., 1995. Nangka dan Cimpedak, Ragam Jenis dan Pembudidayaan. Penebar Swadaya. Jakarta. 